\title{
DIVERSITY OF USED PLANT SPECIES FOR PRODUCING CHARCOAL AND ITS TRADE-OFF IN FAR-NORTH REGION, CAMEROON
}

\author{
G. Todou*, M. Hassan, Akamba Ze, D. Kombo, S. Machewere and T. Vroumsia \\ University of Maroua, Faculty of Science, PO Box: 814, Maroua, Cameroon \\ *Corresponding author: gitodou@gmail.com
}

\section{Abstract}

The Northern Regions of Cameroon belong to sudano-zambesian region. In these regions, woody species are scarce compared to Guinean-Congolese Region and they undergo the human pressure like abusive exploitation of plants. In order to contribute to valorization of phytogenetic resources and contribute to struggle desert progression in sahelian region, a study on plants diversity which are used to produce charcoal and its trade-off was carried out in Far-North Region of Cameroon. Census of plants species was made on the basis of semi-structured surveys through the producers of charcoal and identification of tree trunks on the sites of charcoal production. Data of trade of charcoal was collected by direct observation and a semi-structured survey questionnaire in Maroua. In total, 25 species grouped in 17 genera and 8 families have been recorded. Acacia and Combretum were the richest genera with four species each. They were quoted as multipurpose species which can be used elsewhere as fruits, timbers, medicinal plants or essential oils and exudates. In Maroua almost, $98 \%$ of households use charcoal for heating. In the absence of the charcoal, up to $60 \%$ of those use firewood, $18.46 \%$ use domestic gas and $18.46 \%$ use kerosene. Because of poverty and unemployment, people of primary education are mostly charcoal sellers.

Keywords: Charcoal, plants diversity, trade-off charcoal, valorization of phytogenetic resources, sudano-zambesian.
\end{abstract}




\section{Introduction}

The landscape of Cameroon is characterized by a diversity of vegetation. Evergreen forests are located in the southern part of the country located in the guinean-congolese phytogeographic region. These rainforests harbour a particularly rich and unique biodiversity. The northern Regions belong to sudano-zambesian phytogeographic region (Letouzey, 1985). In this region, woody species are rushed as you go north and they undergo the human pressure like abusive exploitation of plants.

With mounting urbanization, African populations are increasingly shifting from firewood to charcoal for domestic cooking and heating (Girard, 2002). According this author, the shift from firewood to charcoal, even if it lasts only a few decades, could have major ecological consequences if it is not kept under control. These disturbances have caused several declines in wildlife populations and have contributed to the degradation of many tropical forests (Laurance \& Peres, 2006). Over the past 20 - 30 years, threats to African tropical forests in particular have attracted national and international attention.

The Far-North Region of Cameroon is located in sahelo-sudanian. In this zone, firewood and charcoal are the only sources of accessible energy to more than $80 \%$ of rural and urban households (Folefack \& Abou, 2009). Using firewood and charcoal reduce considerably ligneous in the periurban area (Njomgang, 2002). The exploitation of this source of energy became a very important economic activity in Far-North Region. Generally, only $73 \%$ of need of firewood and charcoal are reached (Anonymous, 2014). This is a totally informal sector and it is poorly controlled. Populations' needs for ligneous as energy is strengthened more and more and trained diversification of used species and rapid advance of the desert (Mapongmetsem \& Akagou, 1997). Many ligneous are used as firewood or for charcoal even the wild fruits and medicinal plants.

Concerning charcoal, populations of Maroua consumed approximately 1840 tons in 2010 (Madi, 2011) whereas the number of trees decrease and this favorites projection of desert. For this reason, that the Decree of Governor $N^{\circ} 13 / \mathrm{AR} / \mathrm{K} / \mathrm{SG}$ of May 2010 is a ban on illegal cutting of trees and using charcoal as energy in the Region. However, charcoal continues to be sold and used in this Region abusively. It is urgent to increase awareness for in situ conservation and sustainable use of used species valorizing phytogenetic resources and contributing to struggle desert progression. One of the solutions is to provide permanent and effective reforestation of local species exploited for charcoal. The first step is to identify the exploited species aim to optimize the development of reliable conservation strategies and sustainable use by replanting concerning species.

The main objective of this work is the contribution to raising awareness of the conservation of plant resources in the sudano-zambesian region. The specific objectives are: (1) to identify used species for producing charcoal in Far-Nord Region (Cameroon) and their other use and (2) to characterize the commercialization chain of charcoal in Maroua Region. 


\section{Materials and methods}

\section{Description of study area}

The Far-North Region of Cameroon is situated in the sahel-sudanian zone, mainly between latitude $10^{\circ}$ and $13^{\circ} \mathrm{N}$ and longitude $13^{\circ} 15^{\prime}$ and $15^{\circ} 45^{\prime} \mathrm{E}$ (Figure 1). The dominant species are Acacia albida, Balanites aegyptiaca, Acacia seyal, Ziziphus sp., Combretum sp. In the still drier SahelSahara zone on the banks of Lake Chad, Acacia senegalensis is the only typical species. Periodically flooded grasslands cover an extensive area south of Lake Chad. Where flooding is temporary, the dominant species is Acacia seyal and Acacia nilotica. Where flooding is more permanent, treeless grassland is typical. The dry montane areas of the Alantika and Mandara mountains are intensively cultivated but carry scattered semi-domesticated trees of Acacia albida, Adansonia digitata, Khaya senegalensis, Diospyros mespiliformis, Tamarindus indica and Ziziphus sp. (Boutrais, 1984; Letouzey, 1985). Annual precipitation is $867 \mathrm{~mm}$ on average. The mean annual temperature is $27^{\circ} \mathrm{C}$ with a maximum of $38{ }^{\circ} \mathrm{C}$ from March to April and a minimum of $18{ }^{\circ} \mathrm{C}$ from December to January (Suchel, 1987). Maroua is its country town and it is a cosmopolitan city whose dominant ethnic groups are Giziga, Fulbe, Tupuri, the Moundang, the Massa, the Kanouri, the Mafa and the Musgum. Three villages have been prospected to check off species used to produce charcoal. They are main villages those which supply Maroua in wood energy (Madi, 2011; Anonymous, 2014). They are divided into two Divisions and three Subdivisions: Gabane Tissile (Division of Mayo-Kani, Subdivision of Kaélé), Goudoum-Goudoum (Division of Mayo-Kani, Subdivision of Moulvoudaye) and Sédek (Division of Diamaré, Subdivision of Bogo). 


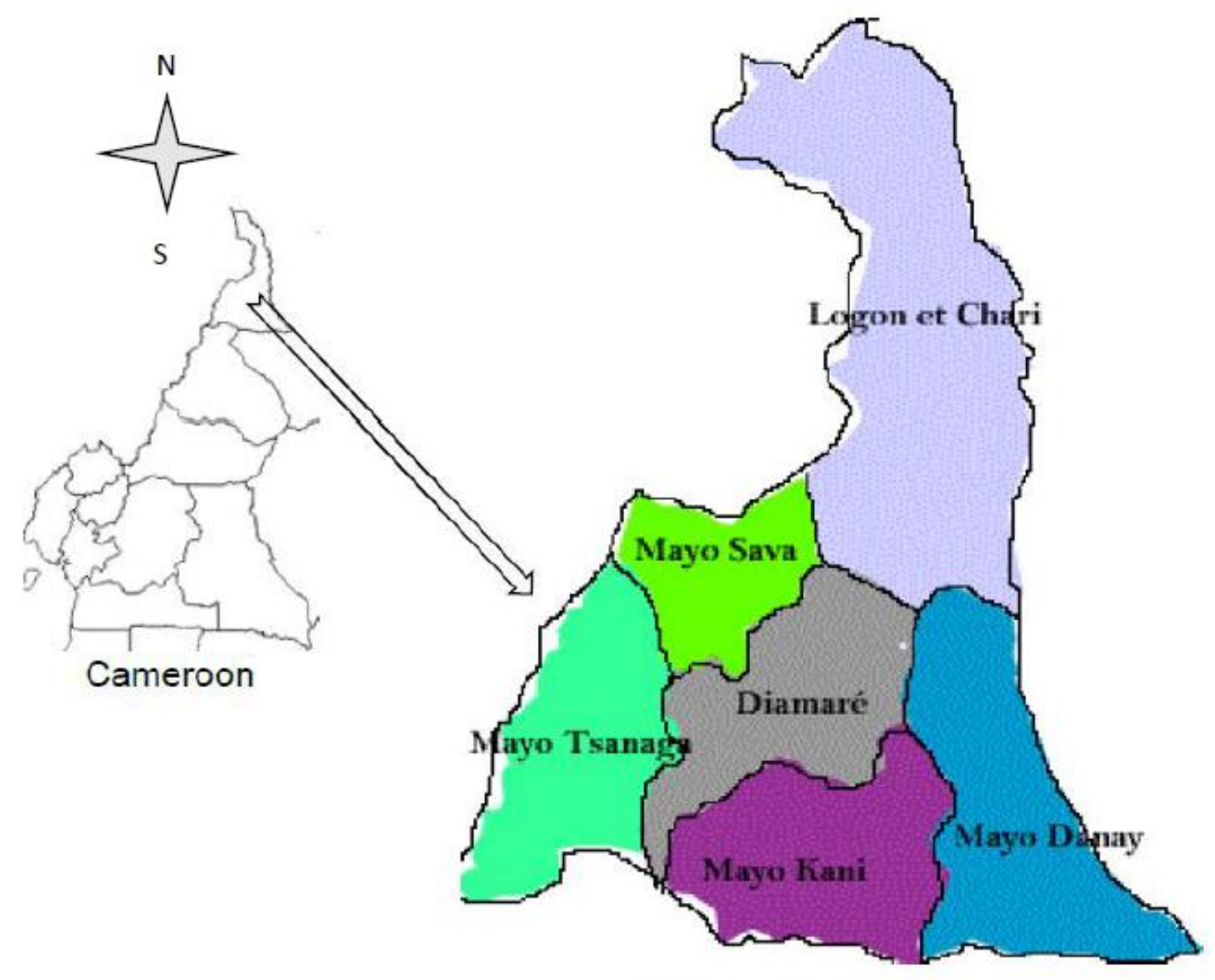

Far-North Region

Figure 1. Location of study site

\section{Identification of species}

Inventory of the species was made on the basis of semi-structured surveys through the producers of charcoal and identification of tree trunks on the sites of charcoal production. Fifteen producers of charcoal per site were interviewed on the used species.

The level of use of the species was assessed by counting the number of trunks belonging to the species and considering the quotations of the producers. The use rate was calculated using this formula:

$$
U R=\left(\frac{S T i+S Q i}{S T t+S Q t}\right) \times 100
$$

$U R=$ Use rate, $S T i=$ Number of observed trunks of species i, SQi $=$ Number of quotations concerning species i, $S T i=$ Total Number of observed trunk of all species, $S Q t=$ Total number of quotations concerning all species.

Local names of these species have been noted. After interview, a trip was organized to the savannahs for samples collection and identification. Scientific names have been authenticated using 
literature (Arbonnier, 2000; Vivien \& Faure, 1996), the lexicon of woody species of NorthCameroon prepared by researchers from IRAD-Maroua and using Herbarium collections available in this Research Centre.

\section{Identification of trade network}

Data of trade of charcoal in Maroua was collected by direct observation and a semi-structured survey questionnaire. This survey was made through 110 sellers (100 retailers and 10 wholesalers) and 320 final consumers (220 heads of households and 100 commercial such as blacksmiths, the fish's braisers, kebabs and coffee owners). A total of 430 individuals located in five quarters (Pitoare, Dougoï, Kakatare, Ouro-Tchédé and Doualaré) were interviewed. These districts are chosen according to the abundance of charcoals in the local markets. Questionnaires for sellers were focused on the social level (age and schooling) and the motivation for selling charcoal. For household consumers, questionnaires focused on the frequency of use of charcoal. All respondents were interviewed on how they supply charcoal and on what is the use level of each species.

\section{Data analysis}

The species were grouped per families and the quantitative abundance of families and of genera were estimated. The local names and the primary uses of plants according PROTA foundation were indicated. Each species was encoded according its use level by the following terms: + = very less used $(10 \% \geq U R) ;++=$ occasional used $(10 \%<U R \leq 50 \%)$ and $+++=$ frequently used $(50 \%<$ $U R)$.

The Statistical Package for Social Sciences software version 20.0 (SPSS, Inc., Chicago, IL, USA) and Excel (Microsoft Office 2013) were used for data processing and presentation of the results.

\section{Result and discussion}

\section{Used plants for producing the charcoal}

In total, 25 species grouped into 17 genera and 8 families were identified as used species to produce charcoal (table 1). Acacia and Combretum were the richest genera with four species each. Fourteen genera have been represented by one species each. Combretaceae family counted eight species grouped in three genera but Caesalpiniaceae totalized five species for five genera. Five families were represented by one only species. There were: Meliaceae (Khaya senegalensis); Fabaceae (Dalbergia melanoxylon); Ebenaceae (Diospyros mespiliformis); Anacardiaceae (Sclerocarya birrea) and Balanitaceae (Balanites aegyptiaca).

The most used species to produce charcoal were Anogeissus leiocarpus, Combretum glutinosum, Acacia hockii, Prosopis africana, Piliostigma thonningii, Diospyros mespiliformis and Balanites aegyptiaca. The least are Faidherbia albida and Terminalia macroptera (Table I). However, Tchobsala (2011) quoted Terminalia macroptera (Combretaceae), Terminalia glaucescens (Combretaceae), Lophira lancealata (Ochnaceae) and Zyzygium guineense var. macrocarpum (Myrtaceae) as the most used species to produce charcoal in the moist savannahs of Adamawa in Cameroon. The surveys done by Mapongmetsem et al. (1997) and Tchotsoua (2006) shown 
Hymenocardia acida was most used species to produce charcoal in Adamawa. The choice of species to produce charcoal can be depended on two factors. The first factor is the availability of plant materials. Some species are very less used or not frequently usedbecause there are few individuals of these species in the zone. This is the case of Terminalia macroptera and Hymenocardia acida which are very less used in the dry savannah of Far-Region but they are most used in the moist savannahs of Adamawa. The second factor to choice species for producing charcoal is based on the quality of the wood. Three important elements have repercussion on the quality of charcoal: the plant species, rate of humidity and rate of lignin. The hard wood produces more charcoal compared with light wood (Sanogo et al., 2006).

All of 25 species checked off are multi-purpose and can be used elsewhere as fruits, timbers, medicinal plants or essential oils and exudates. They are variously and numerously used by local populations. Acacia hockii and Prosopis africana are used primarily as firewood and seven species are used primarily in traditional medicine. Four species are the genuine fruits (Tamarindus indica, Sclerocarya birrea, Balanites aegyptiaca and Diospyros mespiliformis (table I)). These results confirm the ones of Folefack \& Abou (2009), Madi (2011), Saotoing et al. (2011) and Hamawa (2013). According them, some species in Far-North Region in Cameroon are exploited for fruits, for firewood, for traditional medicine, as vegetable or as fodder. The use of wild fruit trees as firewood or for producing charcoal is an indicator of scarcity of ligneous in the savannahs (Mapongmetsem et al., 1997). The excessive exploitation of charcoal and firewood causes desertification that it begins with deforestation leading to a sharp decline of the floristic composition. It is a source of degradation of the plant resources richness in sahelian regions. This degradation concerns the irreversible extinction of biodiversity and the decline of reproduction potential of ligneous resources, pasturage, and soil fertility. It is important to integrate the wild species that are exploited to produce charcoal into the reforestation plans, especially multi-purpose species that are already considered to be endangered locally.

\section{Frequency of use of the charcoal in Maroua as energy and its alternative}

Almost $98 \%$ of the 220 heads of households interviewed in Maroua acknowledged having bought charcoal for heating. However, the frequency of use charcoal depends to the economic level of the household. In the absence of the charcoal, up to $60 \%$ of those use firewood, $18.46 \%$ use domestic gas and $18.46 \%$ use kerosene (Figure 2). The use of electricity remains very marginal (4.62\%). These results showed that firewood and charcoal remain domestic energy in the Region of the FarNorth of Cameroon. In all case, the level of wood and charcoal consumption, despite the use of other energy sources, remains high and gives a dominant character to wood and charcoal as a source of energy in households. This situation has been noted by Madi et al. (2003). It is important to raise awareness of the alternative use of wood and charcoal and gas and petrol, which would reduce wood and charcoal consumption. The demographic growth and the economic crisis in developing countries are at the origin of the use of charcoal and firewood in households (Mapongmetsem et al., 1997). According, Cline-Cole et al. (1990), the size of the family plays an important role in the consumption of energy for cooking. 
Table I. Species used for production of the charcoal in Far-North, Cameroon

\begin{tabular}{|c|c|c|c|c|}
\hline Families & Scientific names & $\begin{array}{l}\text { Local names } \\
\text { (Fulbe) }\end{array}$ & Use levels & Primary uses* \\
\hline \multirow[t]{8}{*}{ Combretaceae } & Anogeissus leiocarpus Guill. \&Perr. & Kodjoli & +++ & Timber \\
\hline & Terminalia avicennioides Guill. \&Perr. & Jabbi-kuulaahi & ++ & Medicinal plant \\
\hline & Combretum adenogonium Steud. ex A. Rich. & Buski & ++ & Medicinal plant \\
\hline & Combretum collinum Fresen. & Buski-deneehi & + & Medicinal plant \\
\hline & Combretum glutinosum Perr. ex DC. & Buski & +++ & Dyes and tannins \\
\hline & Combretum nigricans Lepr. ex Guill. \&Perr. & Dokigori & + & Essential oils and exudates \\
\hline & Terminalia laxiflora Engl. & Foora & + & Medicinal plant \\
\hline & Terminalia macroptera Guill. \&Perr. & Foora-fonnyino & + & Medicinal plant \\
\hline \multirow[t]{7}{*}{ Mimosaceae } & Faidherbia albida (Del.) A. Chev. & Tchaski & + & Auxiliary plant \\
\hline & Entada africana Guill. \&Perr. & Fadowanduhi & ++ & Medicinal plant \\
\hline & Acacia nilotica (L.) Willd. ex Del. & Gawari & ++ & Dyes and tannins \\
\hline & Acacia gerrardii Benth. & Patarlahi & ++ & Fiber \\
\hline & Acacia hockii De Wild. & Tchilouki & +++ & Firewood \\
\hline & Acacia seyal Del. & Oulbehi & ++ & Essential oils and exudates \\
\hline & Prosopis africana (Guill. \&Perr.) Taub. & Kohi & +++ & Firewood \\
\hline \multirow[t]{5}{*}{ Caesalpiniaceae } & Tamarindus indica $\mathrm{L}$. & Djaabé & +++ & Fruit \\
\hline & Piliostigma thonningii (Schumach.) Milne-Redh. & Darkehi & +++ & Fiber \\
\hline & Afzelia africana Smith ex Pers. & Pettohi & ++ & timber \\
\hline & Burkea africana Hook. f. & Djororki-djigahi & ++ & Timber \\
\hline & Detarium microcarpum Guill. \&Perr. & Konkedji & + & Medicinal plant \\
\hline Meliaceae & Khaya senegalensis (Desr.) A. Juss. & Ndalehi & ++ & Timber \\
\hline Fabaceae & Dalbergia melanoxylon Guill. \&Perr. & Galalahi & ++ & Timber \\
\hline Ebenaceae & Diospyros mespiliformis Hochst. ex A. DC. & Nelbi & +++ & Fruit \\
\hline Anacardiaceae & Sclerocarya birrea (A. Rich.) Hochst. & Hédéhi & +++ & Fruit \\
\hline Balanitaceae & Balanites aegyptiaca Del. & Tanné & +++ & Fruit \\
\hline
\end{tabular}

* Primary uses according to PROT A Foundation (Plant Resources of Tropical Africa, www.prota4u.org.). 


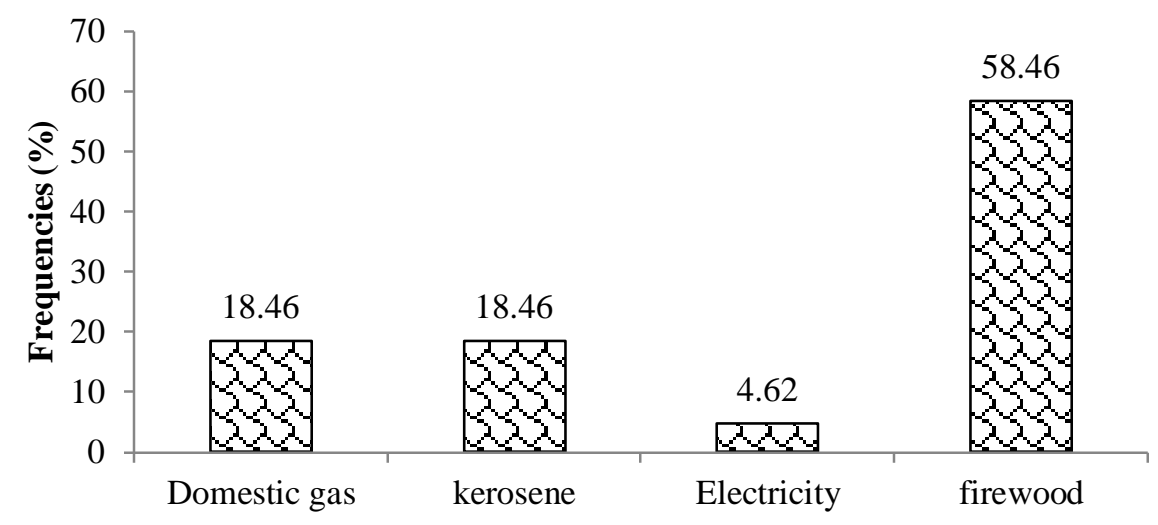

Figure 2. Proportion of use of alternative sources of energy

It is urgent to develop a strategic policy to reduce the frequency of use of woody species as an energy source in order to participate to fight against the advance of the desert in the Sudan-Sahel zone of Cameroon. Most studies on wood energy in Cameroon concern consumption of households. Ndjodo (1982) studying the market of the charcoal in Yaoundé found consumption of about $3.6 \mathrm{~kg} /$ person/year of charcoal. In Douala, Moshiach (1985) estimated that up to reached $3.19 \mathrm{~kg} /$ person per year and more than $317 \mathrm{~kg} / \mathrm{person} / \mathrm{year}$ of fire wood. In Maroua, approximately 1840 tons are consumed in 2010 (Madi, 2011).

\section{Trade of charcoal in Maroua}

Young people ranged between 21 and 30 years old are the most represented with $45.5 \%$ in the charcoal trade. Their schooling level of sellers is low. Up to $82 \%$ did not exceed the primary studies (Figure 3). The sellers of charcoal can be divided into three categories: producers, wholesalers and retailers. The producers of charcoal are the young men who select and cut plants for their job. They are located in rural areas and supply wholesalers and retailers in the city by means of various transports such as bicycles or motorcycles. The wholesalers are the men too. They use big sacks for selling their stocks. Whereas, the retailers are mainly female and they use the small lots about $1 \mathrm{~kg}$ per lot. In the south of Cameroon, a bag of charcoal purchased directly from the producer returns on average to 1000 CFA. It is sold by a wholesaler in the markets of major cities at an average price 1700 CFA (Ahmed, 1998). 


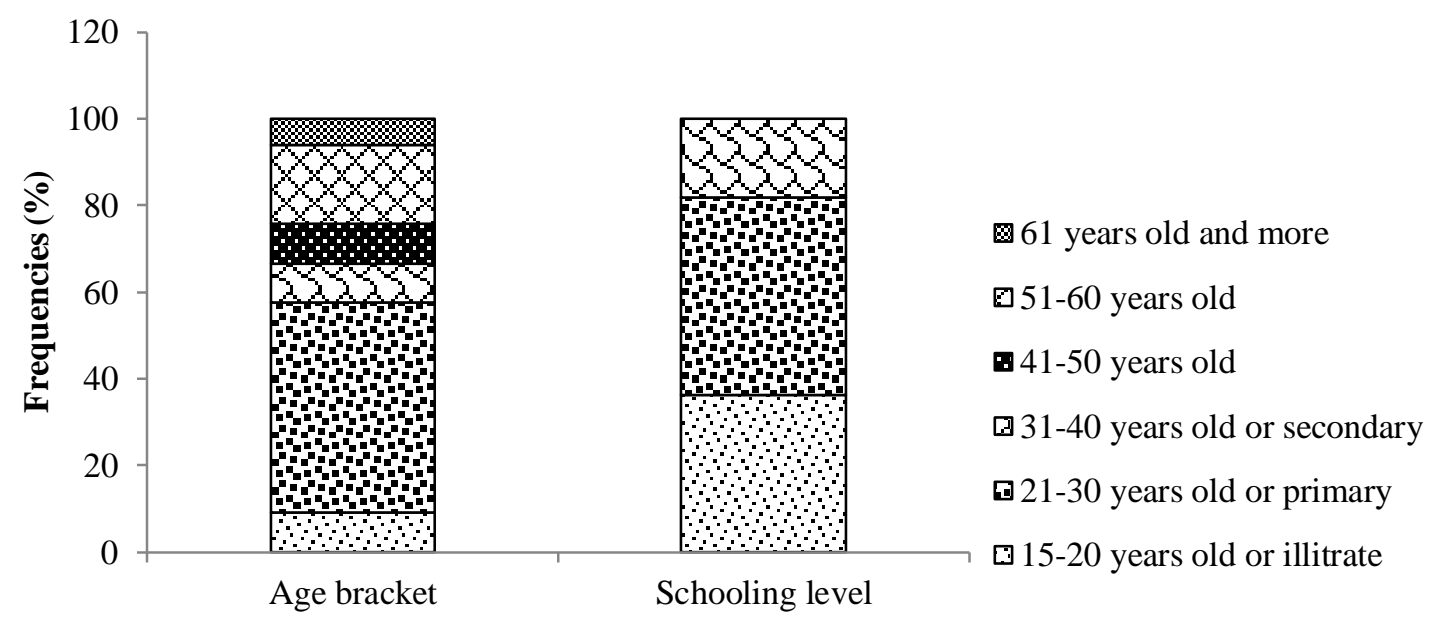

Figure 3. Proportion of sellers of charcoal based on age and schooling level.

In Maroua, consumers are households, manufacturers of pots, blacksmiths, and the barbecue (grill). They mainly get supplies from retailers. They can also get supplies from wholesalers or directly from producers when they need a large amount of charcoal (Figure 4). Some women who prepare beer of sorghum (bil-bil) produce and sell charcoal in small quantities. These women use wood fire to prepare beer and then they put out the embers with water in order to collect charcoal.

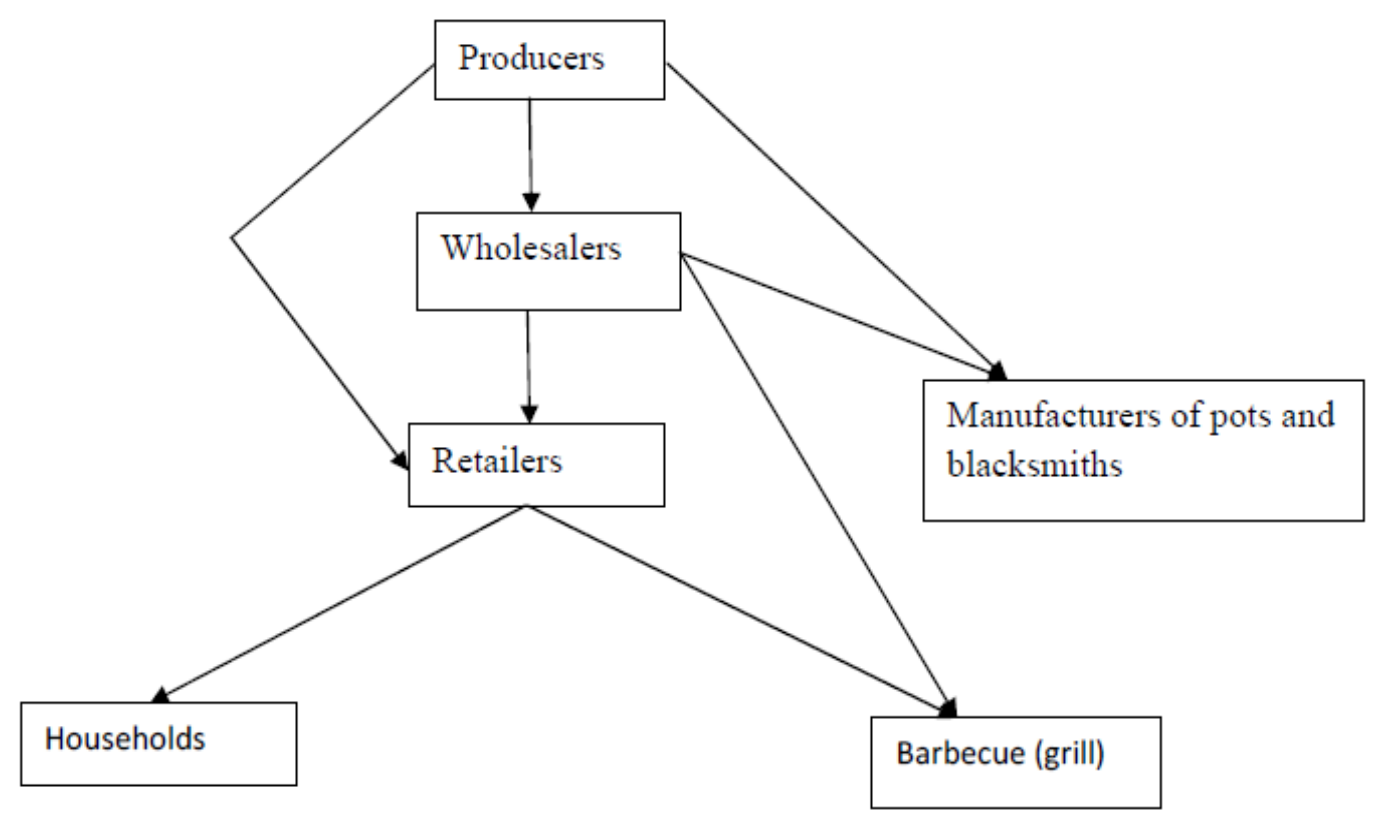

Figure 4. Relationship between the actors of trade of charcoal in Maroua. 


\section{Conclusion}

The used plants species to produce charcoal are numerous and various. They are quoted multipurpose because they can be used for other need as medicinal, timber, fruit or essential oils and exudates. The choice of species to produce charcoal can be depended on two factors. The first factor is the availability of plant materials in the Region. The second factor to choice species for producing charcoal is based on the quality of the wood. The sellers of charcoal can be divided into three categories: producers, wholesalers and retailers. Women who prepare beer of sorghum can produce and sell charcoal in small quantities. The schooling level of all sellers of charcoal Maroua is low (primary studies). The study of diversity used plants for producing charcoal and its commercialization chain in the dry regions is a contribution for increasing awareness for in situ conservation and sustainable use of used species valorizing plant resources and contributing to struggle desert progression. The environmental degradation concerns the irreversible extinction of biodiversity and the decline of reproduction potential of ligneous resources, pasturage, and soil fertility. It is important to integrate the wild species that are exploited to produce charcoal into the reforestation plans, especially multi-purpose species that are already considered to be endangered locally.

\section{References}

Anomous, 2014. Stratégie de Modernisation de la Chaîne de Valeur Bois-Energie dans la Région de l'Extrême Nord, Cameroun. Stratégie de modernisation de la chaine de valeur bois-énergie dans la Région de l'Extrême-Nord, Cameroun. 15 p.

Arbonnier, M., 2000. Arbres, arbustes et lianes des zones sèches d'Afrique de l'ouest. CIRAD, MNHN, UICN. 54 p.

Boutrais, J., 1984. Northern Cameroon: the Men, one Region. Edition of the Office of Scientific Research and Technology.Overseas memorials Wed., 102: 121-143.

Folefack, P.D., Sale Abou, 2009. Commercialisation du bois de chauffe en zone sahélienne du Cameroun. Sécheresse, 20 (3): 312-318.

Girard, P., 2002. Quel futur pour la production et l'utilisation du charbon de bois en Afrique? Unasylva, 211 (53): 30-35.

Hamawa, Y., 2013. Wild edible plants used by Guizigapeople of Far-Nord of Cameroon. International Journal of Medicinal and Aromatic Plants, 3 (2): 136-143. 
Laurance, W.F. and Peres, C.A., 2006. Emerging threats to tropical forests. Chicago: University of Chicago Press. 520 p.

Letouzey, R., 1985. Notice de la carte phytogéographique au 1/500 000. Domaine de la forêt dense humide toujours verte. Institut de la carte Internationale de la Végétation. Toulouse, France: 27-62.

Madi, A., 2011. Étude sur la situation de référence du bois-énergie dans la région de l'Extrême-Nord. Rapport principal-provisoire, Tome 1. ProPSFE. 113 p.

Madi, A., Huub, P., Sali, B., 2003. La demande urbaine en bois energie et la necessite d'une gestion rationnelle des ressources naturelles : la cas de Maroua à L'Extreme-Nord du Cameroun. In Jamin, J.,-Y., Boukar, L.S., Floret, C., (Eds)., Cirad, 9 p., 2003.

Mapongmetsem, P.M., Akagou, Zedong, C.H., 1997. Situation des bois de feu dans les savanes humides de l'Adamaoua. Flamboyant, 42: 29-33.

Njomgang, C., 2002. Economie du bois de feu et environnement au Cameroun. Actes du Colloque International Francophonie et développement durable Dakar, Sénégal, du 11 au 13 mars.

Sanogo, C.A., Elhadji, M.M.L., Khennas,S., Konandji. H., Van Der Plas, J.R., Girard, 2006. Techniques améliorées de carbonisation au Sahel. PREDAS (Programme Régional de promotion des Énergies Domestiques et Alternatives au Sahel), 40 p.

Saotoing, P., Vroumsia Toua, Tchobsala, Tchuenguem Fohouo, F.N., Njan Nloga A.M., Messi, J., 2011. Medicinal plants used in traditional treatment of malaria in Cameroon. Journal of Ecology and the Natural Environment, 3 (3), 104-117.

Suchel, J.B., 1987. Rainfall patterns and regimes rainfall in Cameroon. Doc. Geographic tropical, No. 5,CEGET-CNRS, Talence, 287 p.

Tchobsala, 2011. Impact de coupes de bois sur la végétation naturelle sur la zone périurbaine de Ngaoundéré (Adamaoua). Thèse de Doctarat $/ \mathrm{PhD}$. Université de Yaoundé I, 204 p.

Vivien, J., Faure, J.J., 1985. Arbres des forêts denses d'Afrique centrale. Ministère des Relations Extérieures, Coopération et Développement \& Agence de coopération culturelle et technique, Paris. 